\title{
Effects of epilimnetic versus metalimnetic fertilization on the phytoplankton and periphyton of a mountain lake with a deep chlorophyll maxima
}

\author{
Wayne A. Wurtsbaugh, Howard P. Gross, Phaedra Budy, and Chris Luecke
}

\begin{abstract}
Nutrients can load directly to either the epilimnion or metalimnion of lakes via either differential inflow depths of tributaries or intentional fertilization of discrete strata. We evaluated the differential effects of epilimnetic versus metalimnetic nutrient loading using 17-m-deep mesocosms that extended into the deep chlorophyll layer of oligotrophic Pettit Lake in the Sawtooth Mountains of Idaho. Addition of nitrogen plus phosphorus stimulated primary production nearly identically (2.4- to 4-fold on different dates) in both treatments, with the production peaks occurring in the strata where nutrients were added. The metalimnetic fertilization, however, resulted in equal or greater stimulation of chlorophyll $a$ and phytoplankton biovolume than when nutrients were added directly to the epilimnion. Periphyton growth was stimulated 10-100 times more by epilimnetic fertilization than by metalimnetic fertilization and diverted nutrients from the planktonic autotrophs. These results suggest that the development of deep chlorophyll layers may be influenced by plunging river inflows that carry nutrients to the metalimnion and that metalimnetic lake fertilization may be useful as a tool for increasing lake productivity while reducing the impact on water quality.

Résumé : Les nutriments peuvent s'insérer directement soit dans l'épilimnion, soit dans le métalimnion des lacs selon les différentes profondeurs d'arrivée des eaux des tributaires ou à la suite d'une fertilisation délibérée d'une strate particulière. Nous avons comparé les effets de l'entrée des nutriments dans l'épilimnion et dans le métalimnion à l'aide de mésocosmes de $17 \mathrm{~m}$ de profondeur qui atteignaient la couche profonde de chlorophylle dans le lac oligotrophe Pettit dans les monts Sawtooth en Idaho. L'addition d'azote et de phosphore stimulait la production primaire presque de la même façon dans les deux traitements (d'un facteur de 2,4 à 4 aux différentes dates) et le maximum de production se produisait dans la strate dans laquelle les nutriments avaient été ajoutés. La fertilisation du métalimnion stimulait autant sinon plus la chlorophylle a et le biovolume du phytoplancton qu'une addition des nutriments directement à l'épilimnion. La croissance du périphyton était activée de 10-100 fois plus par une fertilisation de l'épilimnion plutôt que du métalimnion et elle détournait les nutriments des autotrophes planctoniques. Ces résultats laissent croire que la formation des couches profondes de chlorophylle peut être influencée par l'influx en profondeur des eaux de rivière qui apportent des nutriments au métalimnion et que la fertilisation du métalimnion peut être un outil commode pour augmenter la productivité d'un lac, tout en minimisant l'impact sur la qualité de l'eau.
\end{abstract}

[Traduit par la Rédaction]

\section{Introduction}

In oligotrophic lakes and oceans, algal production is often stratified into two distinct layers that may respond differently to nutrient inputs. Growth rates of epilimnetic phytoplankton and periphyton are usually stimulated when nutrients are added, indicating that the populations there are nutrient limited (e.g.,
Marks and Lowe 1993; Downing et al. 1999). In metalimnia where deep chlorophyll layers develop, the relative importance of nutrient limitation is less well understood, and reviews of phytoplankton nutrient limitation have not even addressed these populations (e.g., Downing et al. 1999). Phytoplankton in these layers are thought to be primarily light or temperature limited, with adequate supplies of nutrients diffusing into the

Received September 7, 2000. Accepted August 28, 2001. Published on the NRC Research Press Web site at http://cjfas.nrc.ca on November 2, 2001.

J15959

W.A. Wurtsbaugh. ${ }^{1}$ Department of Fisheries and Wildlife and the Ecology Center, Utah State University, Logan, UT 84322-5255, U.S.A.

H.P. Gross. ${ }^{2}$ Watershed Science Unit, Utah State University, Logan, UT 84321-5200, U.S.A.

P. Budy. U.S. Geological Survey Biological Resources Division, Utah Cooperative Fish and Wildlife Research Unit, Department of Fisheries and Wildlife, Utah State University, Logan, UT 84322-5255, U.S.A.

C. Luecke. Department of Fisheries and Wildlife, Utah State University, Logan, UT 84322-5210, U.S.A.

${ }^{1}$ Corresponding author (e-mail: wurts@cc.usu.edu).

${ }^{2}$ Present address: Hawkwatch International, 1800 South West Temple, \#226, Salt Lake City, UT 84115, U.S.A. 
photic zone from deeper strata (e.g., Cullen 1982). However, results of physiological assays (Pick et al. 1984; St. Amand and Carpenter 1993) and small-scale nutrient addition bioassays (St. Amand and Carpenter 1993; Priscu 1995; Wurtsbaugh et al. 1997) have indicated that phytoplankton in some deep layers can be nitrogen or phosphorus limited. Two whole-lake experiments also suggested that deep chlorophyll layers may be regulated by nutrient concentrations. Nutrient additions to the hypolimnion of a lake in the Experimental Lakes Area of Canada stimulated the development of a large metalimnetic algal population (Schindler et al. 1980), and limited evidence from a metalimnetic fertilization of a large British Columbia lake suggested that these populations could be stimulated by nutrient additions (LeBrasseur et al. 1978).

For periphyton, even less is known about the balance of factors controlling production at different depths in lakes. Most studies on nutrient limitation of attached algae have focused on the shallow littoral zone where nitrogen or phosphorus are frequently limiting (e.g., Mazumder et al. 1989; Marks and Lowe 1993), but Reuter et al. (1985) inferred that periphyton of an oligotrophic lake were also nutrient limited at the depth where the metalimnion intersects the sediments. However, periphyton in deep strata may be exposed to higher dissolved nutrient levels and low light and temperatures that reduce growth. Consequently, like phytoplankton populations, periphyton in deeper strata may have reduced nutrient demands compared with shallow littoral populations.

If algae in shallow and deep strata respond differently to nutrient additions, then the depth at which nutrients load into a system could have important consequences for the distribution and magnitude of lake productivity. Although we often perceive that nutrients enter primarily into the epilimnion, this is not always the case. If inflowing river water is cooler and thus denser than a lake's epilimnion, it will plunge and interflow into the metalimnion (Carmack et al. 1979). If nutrients in the river water are thus diverted from the epilimnion and fed directly to the metalimnia, deep chlorophyll layers could develop. Within-lake processes will also distribute nutrients to different strata. Sedimentation will move nutrients to deeper strata, whereas eddy diffusion usually moves nitrogen and phosphorus from deep, nutrient-rich strata to shallower ones. Nutrients from the sediments in contact with the epilimnion may also contribute to production in that strata (Fee 1979), and MacIntyre et al. (1999) recently suggested that breaking internal waves can move nutrients from the metalimnetic-sediment interface into the metalimnion.

The depth of nutrient entry may have important implications for lake modeling and management. Firstly, most eutrophication models neglect depth-specific nutrient loading and the movement of nutrients between strata. If loading occurs to the metalimnion, phytoplankton in the deep chlorophyll layer may be stimulated without increasing algal abundance in the epilimnion, which is most frequently sampled to track eutrophication. Secondly, the epilimnia of lakes are sometimes fertilized to increase fish production (e.g., Budy et al. 1997). If algae living in the metalimnia are also nutrient limited, these layers could be fertilized to increase food-web production, perhaps without the negative effect of decreasing water transparency in the epilimnion.

The objective of our work was to measure the differential effects of metalimnetic versus epilimnetic fertilization on the growth of phytoplankton and periphyton and on water clarity in lakes in the Sawtooth Mountains of Idaho. In 1993, we used large mesocosms in one of these lakes to test whether (i) metalimnetic fertilization could be used to increase plankton growth and assist in the recovery of endangered Snake River sockeye salmon (Oncorhynchus nerka) that inhabit these lakes and (ii) the plunging river inflows that enter these lakes might contribute to the formation of deep chlorophyll layers.

\section{Methods}

\section{Study site}

The experiment was done in Pettit Lake, located in the Sawtooth National Recreation Area in central Idaho (latitude $44^{\circ}$, longitude $115^{\circ}$ ) at an elevation of $2132 \mathrm{~m}$. This steep-sided cirque lake has a surface area of $1.62 \mathrm{~km}^{2}$ and mean and maximum depths of $28 \mathrm{~m}$ and $52 \mathrm{~m}$, respectively. The lake's $27 \mathrm{~km}^{2}$ watershed lies in the pristine, granitic Sawtooth Mountains. The lake basin is precipitous, and at the stream inflow, the bottom inclines at an angle of $25^{\circ}$, reaching $20 \mathrm{~m}$ deep $41 \mathrm{~m}$ from shore. The lake is dimictic and meromictic, with a biogenically formed monomolimnion below $40 \mathrm{~m}$ in a small, deep, central depression. Summer epilimnetic temperatures reach $18^{\circ} \mathrm{C}$. During summer stratification, the metalimnion extends from about $6 \mathrm{~m}$ to $25 \mathrm{~m}$, with temperatures ranging from 16 to $5^{\circ} \mathrm{C}$. Light intensities in the metalimnion range from about $30 \%$ to $0.2 \%$ of surface intensities.

The lake is oligotrophic, with mean summer epilimnetic total nitrogen (TN) and total phosphorus (TP) concentrations of $6 \mu \mathrm{M}$ and $0.2 \mu \mathrm{M}$, respectively (Gross et al. 1994). Epilimnetic dissolved inorganic carbon concentrations are also low, averaging $0.12 \mathrm{mM}$. Pettit Lake is primarily limited by nitrogen and secondarily by phosphorus (Wurtsbaugh et al. 1997). The mean summer epilimnetic chlorophyll $a$ concentration is near $0.5 \mu \mathrm{g} \cdot \mathrm{L}^{-1}$, and the mean Secchi depth is $14 \mathrm{~m}$. The phytoplankton in the lake are dominated by Chlorophyta (Chlorella spp., Oocystis spp., and others in the group Chlorococcales). The chrysophyte Dinobryon sp. is also important in the epilimnion and metalimnion. Except in early summer, diatoms represent less than $10 \%$ of the phytoplankton biovolume. Cyanobacterial picoplankton are abundant, with about $40 \%$ of chlorophyll $a$ occurring in the $<1 \mu \mathrm{m}$ size fraction (Budy et al. 1995).

During summer, a broad deep chlorophyll layer develops between $6 \mathrm{~m}$ and $35 \mathrm{~m}$ with the maxima near $25 \mathrm{~m}$ at light levels less than $1 \%$ of surface intensities (Fig. 1; Gross et al. 1997). We refer to the deep chlorophyll layer (DCL) as the entire portion of the water column below the epilimnion where phytoplankton abundance is high and the deep chlorophyll maxima (DCM) as only the peak of abundance occurring deep in the water column. The mechanisms forming and maintaining DCLs are controversial and not yet completely understood (Cullen 1982). In Pettit and other lakes of the Sawtooth Mountains, it seems likely that they are formed because plunging river inflows in the spring deliver nutrients to deep strata (W. Fleenor and W. Wurtsbaugh, unpublished data), and they are maintained because high macrozooplankton grazing in the epilimnia removes phytoplankton from the epilimnia and transports nutrients into the metalimnia (A. Pilati and W. Wurtsbaugh, unpublished data).

The dominant crustacean zooplankter in Pettit Lake is Daphnia rosea, followed by Holopedium gibberum and Bosmina longirostris (Budy et al. 1995). Macrozooplankton biomass in the lake and in our experimental enclosures (see below) varied from 25 to $240 \mu \mathrm{g}$ dry weight $\cdot \mathrm{L}^{-1}$ over the course of our experiment. Using grazing rates given in Peters (1984), we estimate that community filtration 
Fig. 1. Profiles of temperature (dotted line) and chlorophyll $a$ (-O) and the 1\% light level in Pettit Lake on 7 August 1993, midway through the experiment. Also shown are concentrations of dissolved inorganic nitrogen (DIN, $\mathrm{NO}_{3}^{-}+\mathrm{NH}_{4}{ }^{+}$) collected on several dates during the summer of 1993 (A) from Gross et al. (1994) and the mean DIN concentrations profile for the summers of 1992-1995 (broken line). The position of the limnocorrals used in the experiment is shown relative to the deep chlorophyll layer.

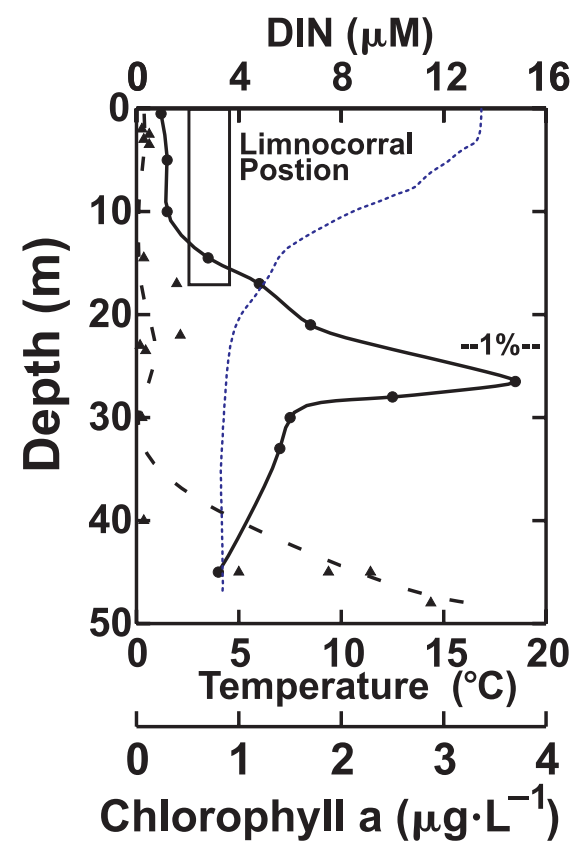

rates were low, ranging from 1 to $12 \% \cdot \mathrm{day}^{-1}$. Emergent macrophytes are absent, and submerged macrophytes densities are low in the lake.

Pettit Lake and other lakes in the Sawtooth Mountains once had abundant populations of Snake River sockeye salmon, but dam construction and other factors have caused these populations to decline $>99 \%$ since the 19th century (Gross et al. 1998). In 1992, managers began a hatchery brood stock program to avert extinction of the species. At the time of our study, managers were also considering fertilizing Pettit and other lakes in the region to increase plankton production and the growth and survival rates of juvenile sockeye salmon introduced from the brood stock program. These lakes are in a pristine setting and are highly valued for recreational and aesthetic purposes. Ideally, a fertilization program to help recover the salmon would minimally impact water clarity but increase primary and secondary productivity.

\section{Mesocosm analyses of epilimnetic and metalimnetic fertilization}

The nutrient-addition experiments were conducted over a 10week period in six $330 \mathrm{~m}^{3}$ mesocosms, or limnocorrals (Aquatic Research Instruments, Inc., Lemhi, Idaho), located in the pelagic region of Pettit Lake. Each cylindrical limnocorral was $5 \mathrm{~m}$ in diameter and $17.5 \mathrm{~m}$ deep with tops that floated above the lake surface. They were constructed with weighted curtains of impermeable, fiber-reinforced polyethylene. The limnocorrals were unfurled slowly (12 h) through the water column with the bottoms open; thus the initial conditions were similar to those in the lake. Once filled, SCUBA divers tied the bottoms closed and sand bags were placed inside to further seal the closure and to provide ballast to keep the limnocorrals vertical. The limnocorrals extended only into the upper portion of the deep chlorophyll layer of the lake (Fig. 1).
Each limnocorral was randomly assigned one of three treatments, with two replicates each: (1) control (CNTL); (2) nitrogen and phosphorus added to the epilimnion (EPI); and (3) $\mathrm{N}$ and $\mathrm{P}$ injected into the metalimnion at a depth of $14.5 \mathrm{~m}$ (META). At the start of the experiment on 3 July 1993, TN concentrations in the limnocorrals were 6.0 (range of $4.8-6.8) \mu \mathrm{M}$ and TP levels were 0.14 (range of $0.12-0.17) \mu \mathrm{M}$. Over the course of the summer, we approximately doubled the nutrients, adding $8.6 \mu \mathrm{M}$ and $0.19 \mu \mathrm{M}$ of $\mathrm{N}$ and $\mathrm{P}$, respectively, to the EPI and META treatments. $\mathrm{N}$ and $\mathrm{P}$ were added as $\left(\mathrm{NH}_{4}\right)_{2} \mathrm{HPO}_{4}$ and $\mathrm{NH}_{4} \mathrm{NO}_{3}$, at a 43:1 molar ratio to reduce the likelihood of stimulating nitrogen-fixing cyanobacteria. Weekly epilimnetic nutrient additions were stirred in at the surface; in the META treatment, they were injected at $14.5 \mathrm{~m}$ using a hose and limnocorral water of a temperature equal to that at $14.5 \mathrm{~m}$. Fifty percent of the nutrients was added during the first week of the experiment to provide an initial, large injection; the remaining $50 \%$ was added in equal parts over the following nine weeks.

\section{Physical, chemical, and biological measurements}

In Pettit Lake and in each limnocorral, we measured temperature and oxygen profiles biweekly with a Hydrolab® H20 Multiparameter Water Quality Data Transmitter (Hydrolab Corp., Austin, Texas). Water transparency was measured weekly with a $25-\mathrm{cm}-$ diameter Secchi disk.

Lugol's-preserved phytoplankton samples $(100 \mathrm{~mL})$ from discrete depths were filtered through $0.45-\mu \mathrm{m}$ cellulose acetate filters, cleared, and permanently mounted according to the method of Crumpton (1987). Cells were counted in a minimum of 10 fields per slide at $400 \times$, which always yielded counts of over 100 individuals in dominant taxa. The dimensions of a minimum of 10 individuals in each taxa (usually genera) were measured to calculate biovolume. Ten measurements should have provided a standard error of $<10 \%$ of the mean (Hillebrand et al. 1999). Phytoplankton taxa were identified according to Prescott (1978) and are reported here in the following taxa: Cyanobacteria (blue-green algae), Chlorophyta (green algae), Chrysophyta (primarily Dinobryon sp.), Bacillariophyta (diatoms), and Dinophyta (primarily Peridinium sp.). Picocyanobacteria were not counted.

At weekly intervals, we collected water for chlorophyll $a$ analysis from the epilimnion $(0-4$ or $0-6 \mathrm{~m})$ and from $0-17 \mathrm{~m}$ in each limnocorral with depth-integrating vinyl tubes. Additional depths were sampled with a 4 - $\mathrm{L}$ Van Dorn bottle when ${ }^{14} \mathrm{C}$ primary productivity measurements were made (see below). Samples for chlorophyll analysis were filtered on $0.45-\mu \mathrm{m}$ membrane filters that should have retained nearly all phytoplankton and picocyanobacteria. The filters were extracted in methanol and analyzed fluorometrically before and after acidification $\left(2.5 \times 10^{-3} \mathrm{M} \mathrm{HCl}\right)$ with a Turner Model 111 fluorometer (Holm-Hansen and Riemann 1978). On three dates, ${ }^{14} \mathrm{C}$ primary productivity measurements were made at five depths in each limnocorral following methods of American Public Health Association (1992) with the exception that incubations were done in $25-\mathrm{mL}$ glass scintillation vials suspended horizontally in transparent acrylic tubes. Reported rates of primary production were corrected for nonphotosynthetic uptake but do not include dissolved organic carbon fixed and excreted by the phytoplankton.

To quantify periphyton growth and (or) attachment, we suspended a weighted strip of polyethylene limnocorral material $10 \mathrm{~cm}$ wide $\times 17 \mathrm{~m}$ long in the center of each corral. At intervals, we bored two replicate 14-mm-diameter disks from each strip with a cork borer at 5-6 depths. Chlorophyll was extracted from these disks in $100 \%$ methanol for $24-48 \mathrm{~h}$ in the dark and then analyzed fluorometrically.

We attempted to use age- 0 redside shiners in the limnocorrals to evaluate effects of nutrient additions on fish growth. Fifteen 0.3- to 0.5-g fish were placed in each corral. Unfortunately, the fish were extremely sensitive to handling and few survived (Gross et al. 
Fig. 2. Depth profiles of primary production measured on three dates in the Pettit Lake limnocorrals. Individual profiles are shown for the controls (CNTL, solid line), epilimnetic fertilizations (EPI, dotted line), and metalimnetic fertilizations (14. 5 m; META, broken line): (a) 5 July, (b) 31 July, (c) 29 August 1993. The profiles on 5 July were made 2 days after the initiation of fertilization. Bars on symbols show ranges of production in the duplicate limnocorrals.

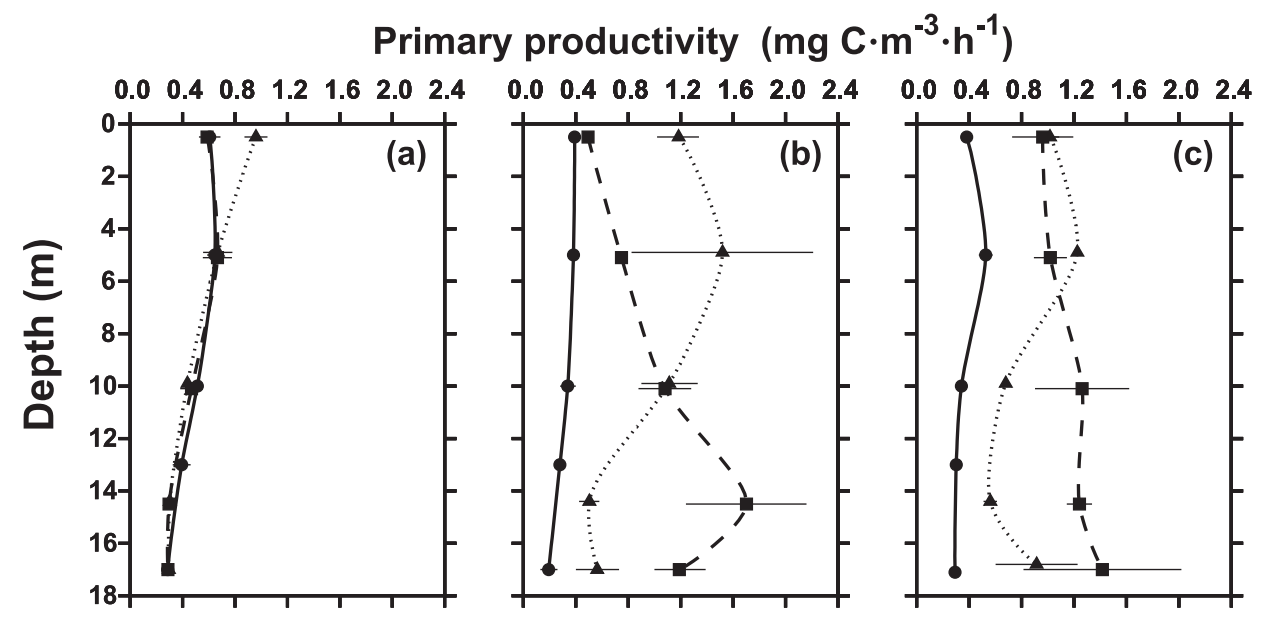

1994). Because more than $90 \%$ of these fish could not be accounted for and were assumed to have died, no conclusions about planktivory or fish growth in response to nutrient additions could be made. Release of nutrients from the dead fish should have had a minimal influence on the phytoplankton, as they should have contributed approximately $0.05 \mu \mathrm{M} \mathrm{N}$ and $0.03 \mu \mathrm{M} \mathrm{P}$ to each limnocorral, or less than $3 \%$ of the initial nutrient concentrations. Zooplankton densities were measured with vertical hauls of a $30-\mathrm{cm}-$ diameter net in the center of the limnocorrals.

In most cases, we analyzed the data with repeated-measures analysis of variance (RM-ANOVA), followed by Tukey's post-hoc tests to determine which of the treatments differed from each other (SAS Institute Inc. 1988).

\section{Results}

Planktonic primary production, temperature, and oxygen

Temperature and oxygen profiles closely paralleled the conditions observed in the lake, and there was little difference among treatments on each date. Throughout the experiment, both the limnocorrals and the lake were thermally stratified, with 4- to 6-m-thick epilimnia at temperatures of $11-16^{\circ} \mathrm{C}$, and metalimnia declining to $5.5-6.0^{\circ} \mathrm{C}$ at $17 \mathrm{~m}$. Dissolved oxygen in all of the corrals was $>5.0 \mathrm{mg} \cdot \mathrm{L}^{-1}$ at all depths throughout the experiment.

Nutrient additions markedly increased primary productivity in the limnocorrals, and the stimulation was greatest in the strata where the nutrients were added (Fig. 2). Primary production was first measured 2 days after nutrient additions began. On this date, productivity was similar among the treatments, except at $0.5 \mathrm{~m}$ in the EPI treatments, where mean algal growth was over $50 \%$ greater than in the CNTL treatments, suggesting that the phytoplankton responded quickly to the nutrient additions in surface waters where light and temperatures were relatively high (Fig. 2a). By the end of July, the spatial differences in productivity among the three treatments were well established (Fig. 2b). In the EPI treatments, production in the epilimnion was approximately $200 \%$ greater than in the controls. This enhanced productivity extended to $10 \mathrm{~m}$ but declined in the deeper water. In the metalimnetic fertilizations, production in the deeper waters was $400 \%$ greater than in the controls, whereas the stimulation was less pronounced in the epilimnia. By the end of August, the spatial differences in productivity among the treatments were less distinct, but the pattern established in July was still evident (Fig. 2c).

The integrated water column estimates of total production demonstrated that epilimnetic and metalimnetic fertilizations had comparable overall influences on algal growth (Fig. 3). Two days after the fertilization began (5 July), total integrated productivity was similar in all three treatments $\left(F_{[2,3]}=0.27, p=0.780\right)$, indicating that there had been insufficient time for a significant water column response to fertilization. By late July and late August, mean rates of primary production were approximately $190 \%$ higher in both the EPI and META treatments than in the controls, and these results were highly significant (one-way ANOVAs: July, $F_{[2,3]}=30.7, p=0.010$; August, $\left.F_{[2,3]}=154, p<0.001\right)$. Integral rates of primary productivity were never significantly different in the EPI and META treatments (post-hoc Tukey's, $\alpha=0.05$ ), but productivity in each of these treatments was highest in the strata of the nutrient addition (Fig. 3).

\section{Planktonic biovolume, chlorophyll, and water transparency}

Algal biovolume response was generally similar to the response of primary productivity, with nutrients stimulating the phytoplankton most in the strata where they were applied. Two days after the start of the experiment (5 July), the phytoplankton community structure was similar in all three treatments, with a mixture of Chlorophyta, diatoms, and Dinobryon spp. at all depths (Fig. 4). The chlorophytes were dominated by Oocystis sp., Chlorella spp., and other small algae in the group Chlorococcales. The dominant diatom was Cyclotella sp. The biovolume at $17 \mathrm{~m}$ was about 3 times greater than at the surface, reflecting the deep chlorophyll layer developing in the lake below the thermocline (Fig. 1). Over the course of the experiment, biovolumes in the control mesocosms declined somewhat, principally owing to decreases in Cyclotella sp. and Dinobryon spp. 
The nutrient additions significantly increased total phytoplankton biovolumes (RM-ANOVA, $F_{[2,3]}=8.2, p=0.055$ ) and changed the community composition. After 4 weeks of nutrient additions (31 July), phytoplankton in the EPI treatment had increased markedly at all depths (Fig. 4). The increase was pronounced in the epilimnion where biovolume was more than $5000 \%$ above controls resulting from blooms of the diatom genera Fragilaria, Tabellaria, Asterionella, and Synedra spp. Epilimnetic increases of Chlorophyta mainly were due to Spondylosium sp. The cyanobacteria Oscillatoria sp. also increased in the epilimnia, but this made up only $6 \%$ of the total biovolume. In the metalimnetic fertilization, increases in mean algal biovolumes were greatest at depth $(59,582$, and $822 \%$ above controls at $0-4,10$, and $17 \mathrm{~m}$, respectively). Increases in diatoms were from the same taxa as in the EPI treatments, whereas Oocystis sp. was the primary chlorophyte stimulated by fertilization. After 8 weeks (29 Aug.), biovolumes in EPI treatment did not differ markedly from controls in the epilimnion or at $10 \mathrm{~m}$ but were $375 \%$ above control levels at $17 \mathrm{~m}$. In the EPI treatment, the Fragilaria sp. bloom from 31 July was virtually gone, and the communities at all depths were dominated by the chlorophytes Spondylosium sp. and Gloeocystis sp. In the META treatments, biovolumes and taxonomic composition in the epilimnion were similar to controls. At $10 \mathrm{~m}$, however, the biovolume was $100 \%$ higher than in controls, and at $17 \mathrm{~m}$, it was $740 \%$ higher. These increases primarily were due to the continuing bloom of Fragilaria sp., to increases in Chlorella sp. in the deep water, and to Dinobryon sp. at $10 \mathrm{~m}$.

Variability in zooplankton abundance was high between replicate limnocorrals, and the biomass of zooplankton was not significantly influenced by the nutrient treatments (ANOVA, $p=0.704)$. The zooplankton biomass was dominated by $D$. rosea, which usually represented $60-95 \%$ of the biomass in all corrals. Bosmina longirostris initially represented $40 \%$ of the biomass in the corrals. Within 3-4 weeks, they nearly disappeared in the controls but remained near $15-30 \%$ of the biomass in the epilimnetic and metalimnetic fertilization treatments. The combined densities of H. gibberum, P. pediculus, and cyclopoid copepods represented less than $10 \%$ of community biomass. Details of the zooplankton densities are provided in Gross et al. (1994).

Nutrient additions also significantly increased chlorophyll levels above controls. This effect was most pronounced when $\mathrm{N}$ and $\mathrm{P}$ were added to the metalimnion (Fig. 5). Fertilization of the metalimnion increased chlorophyll levels markedly at 14.5 and $17 \mathrm{~m}$ and slightly at 0$5 \mathrm{~m}$. Epilimnetic fertilization also stimulated chlorophyll at all depths. In the EPI treatment, chlorophyll levels in the epilimnion were more than twice those of the control treatments on most dates but were often 3-4 times higher in the deeper strata. The integrated, 0-17-m tube samples yielded weekly mean chlorophyll concentrations of $0.91,1.42$, and $2.56 \mu \mathrm{g} \cdot \mathrm{L}^{-1}$ for the CNTL, EPI, and META treatments, respectively (Fig. 6a), and these results were highly significant (RM-ANOVA, $\left.F_{[2,2.97]}=26.2, p=0.013\right)$. Only the META means were significantly different from the CNTRL means (post hoc Tukey's comparison, $\alpha=0.05$ ). However, the mean integrated $0-17 \mathrm{~m}$ chlorophyll concentrations for the META treatments were greater than those in the EPI
Fig. 3. Integrated water column $(0-17 \mathrm{~m})$ primary productivity in the limnocorrals. Initial measurements were taken on 5 July, just 2 days after fertilization began in control (C), epilimnetic fertilization (E), and metalimnetic fertilization (M) treatments. Production for the controls (CNTL), epilimnetic (EPI), and metalimnetic (META) are shown for 31 July and 29 August 1993. The solid histogram sections indicate primary production (mean + standard error) in the metalimnion $(7.5-17.5 \mathrm{~m})$, and the open sections indicate primary production in the epilimnia $(0-7.5 \mathrm{~m})$. Integrated primary production was significantly different among treatments only on 31 July and 29 August (July, $F_{[2,3]}=30.7, p=0.010$; August, $F_{[2,3]}=154, p<0.001$ ).

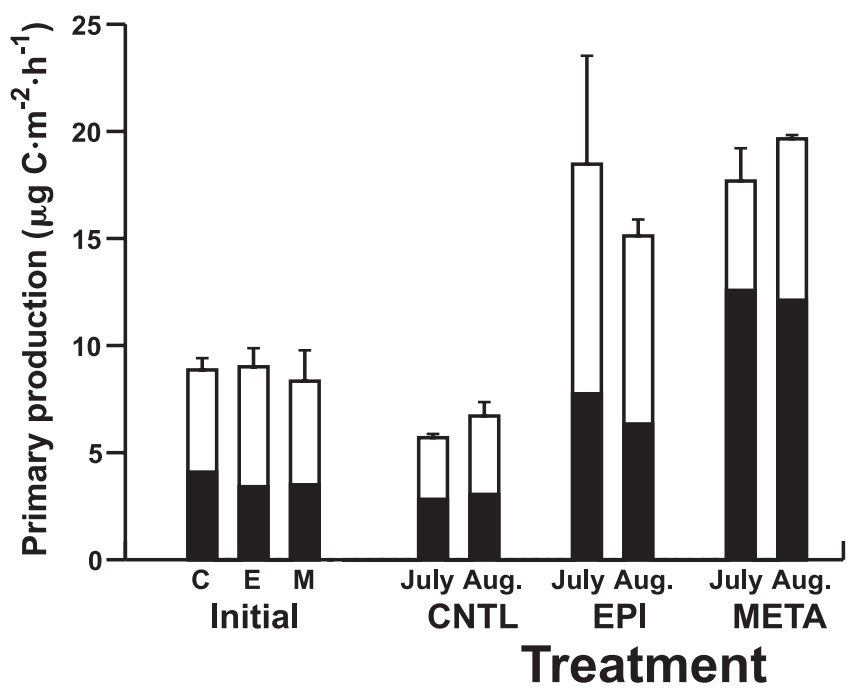

treatment for all 10 weekly samplings after nutrient additions began. The mean weekly chlorophyll levels in the epilimnion were $0.31,0.74$, and $0.67 \mu \mathrm{g} \cdot \mathrm{L}^{-1}$ for the CNTL, EPI, and META treatments, respectively. Although there was a significant treatment effect (repeated measures ANOVA, $\left.F_{[2,3]}=223, p<0.001\right)$, the EPI and META means were not significantly different from each other (post-hoc Tukey's comparison, $\alpha=0.05$ ). Chlorophyll concentrations in the control limnocorrals tracked levels in the lake reasonably well for the first month but had declined to $40 \%$ of those in the lake by the end of the experiment.

Fertilization significantly decreased water transparency in the limnocorrals $(p=0.008)$, with respective mean Secchi depths for the CNTL, META, and EPI treatments of 13.7, 11.4, and $10.9 \mathrm{~m}$ (Fig. 7). The mean transparency in the control limnocorrals was nearly identical with that in the lake $(13.8 \mathrm{~m})$. Owing to the low level of fertilization, water transparency was greater than $8 \mathrm{~m}$ in all of the treatments throughout the experiment. Secchi depths were deeper in the META treatments than in the EPI treatments on 8 of 11 dates, but the difference was not significant (post hoc Tukey's, $\alpha=0.05)$.

\section{Periphyton growth}

Nutrient additions stimulated periphyton chlorophyll levels up to three orders of magnitude (Figs. $8 a-8 c$ ), and the differences among treatments were highly significant (RMANOVA of log-transformed data, $\left.F_{[2,3]}=123.0, p=0.001\right)$. In the control limnocorrals, periphyton increased gradually 
Fig. 4. Mean biovolumes of cyanobacteria (black), Chrysophyta (diagonal hatching), Chlorophyta (open), and Bacillariophyta (vertical hatching) in the limnocorrals at epilimnetic (0-4 or $0-6 \mathrm{~m})$, metalimnetic (9 or $10 \mathrm{~m})$, and near-bottom (17 m) depths. Shown are responses in controls (CNTL) and in epilimnetic (EPI) and metalimnetic (META) nutrient treatments. Biovolumes are shown for $(a, b, c) 5 \mathrm{July},(d, e, f) 31 \mathrm{July}$, and $(g, h, i) 29$ August 1993. Total biovolume differences among treatments were significant (RMANOVA, $\left.F_{[2,3]}=8.82, p=0.055\right)$. The arrow in $(e)$ indicates that total algal biovolume in the epilimnion reached $2.7 \times 10^{6} \mu \mathrm{m}^{3} \cdot \mathrm{mL}^{-1}$.

\section{Treatment}

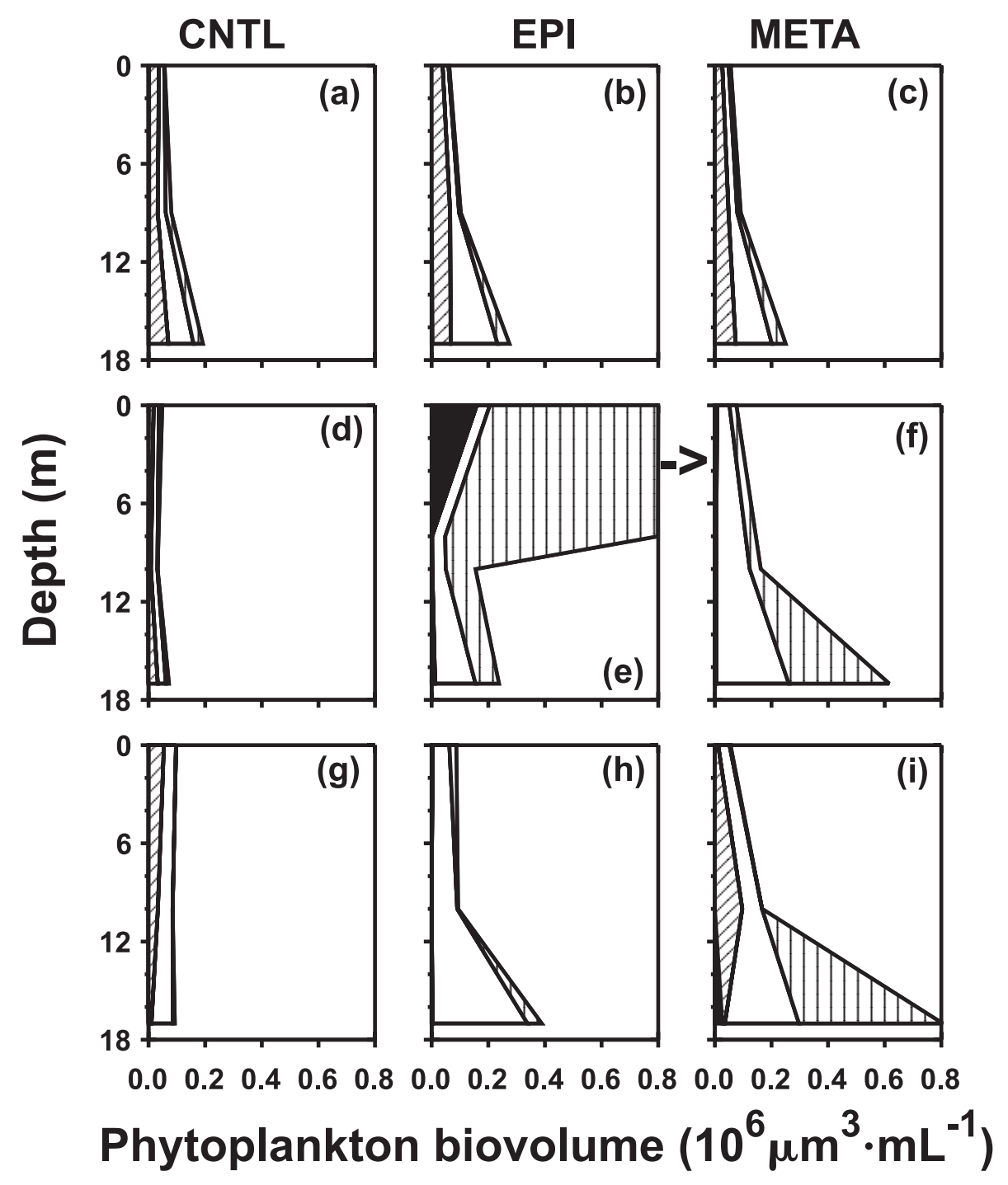

throughout the experiment, but algae were barely detectable by eye and chlorophyll levels never surpassed $0.1 \mathrm{mg} \cdot \mathrm{m}^{-2}$. In the EPI treatments, however, 5- to 10-mm-thick patches of periphyton developed near the top of the limnocorral walls, and chlorophyll concentrations there reached $2.3 \mathrm{mg} \cdot \mathrm{m}^{-2}$ within 4 weeks (Fig. $8 a$ ). As the experiment progressed, periphyton in the EPI treatment spread deeper along the limnocorral walls (Fig. 8b). By the end of the experiment (Fig. 8c), periphyton levels in the EPI treatments started to decline near the tops of the limnocorrals. In the META treatments, periphyton was moderately stimulated throughout the water column but particularly in the lower depths where chlorophyll levels reached $2 \mathrm{mg} \cdot \mathrm{m}^{-2}$. Periphyton levels in the META treatment increased as the experiment progressed, eventually exceeding EPI treatment levels at 13 and $17 \mathrm{~m}$ after 10 weeks of fertilization (14
Sept.; Figs. $8 a-8 c$ ). Total chlorophyll levels of periphyton were significantly higher in the EPI than in the META treatments after 4 and 7 weeks of fertilization but not after 10 weeks (post hoc Tukey's comparisons, $\alpha=0.05$ ).

To compare the relative "biomass" of phytoplankton and periphyton in the limnocorrals, we calculated the total amount of chlorophyll $a$ of each component for each strata and then integrated the chlorophyll amounts over depth. Throughout the experiment, the amount of periphyton chlorophyll in the CNTL treatments was $<4 \%$ of the total chlorophyll in the limnocorrals (Fig. 9). In the EPI treatments, however, chlorophyll in the periphyton represented between 20 and $50 \%$ of the total on different dates. In the META treatments, periphyton developed slowly, and it never represented more than $20 \%$ of the total chlorophyll in the limnocorrals. Although the effect of nutrient additions on 
Fig. 5. Vertical profiles of mean chlorophyll $a$ on three dates in control (CNTL, solid line) limnocorrals and in those fertilized in either the epilimnion (EPI, short-dashed line) or metalimnion (META, long-dashed line). (a) Chlorophyll distributions on the first day of fertilization (3 July). Responses on (b) 31 July and (c) 29 August 1993. Bars on symbols indicate ranges $(n=2)$. The highest range bars in $(b)$ and $(c)$ are truncated.

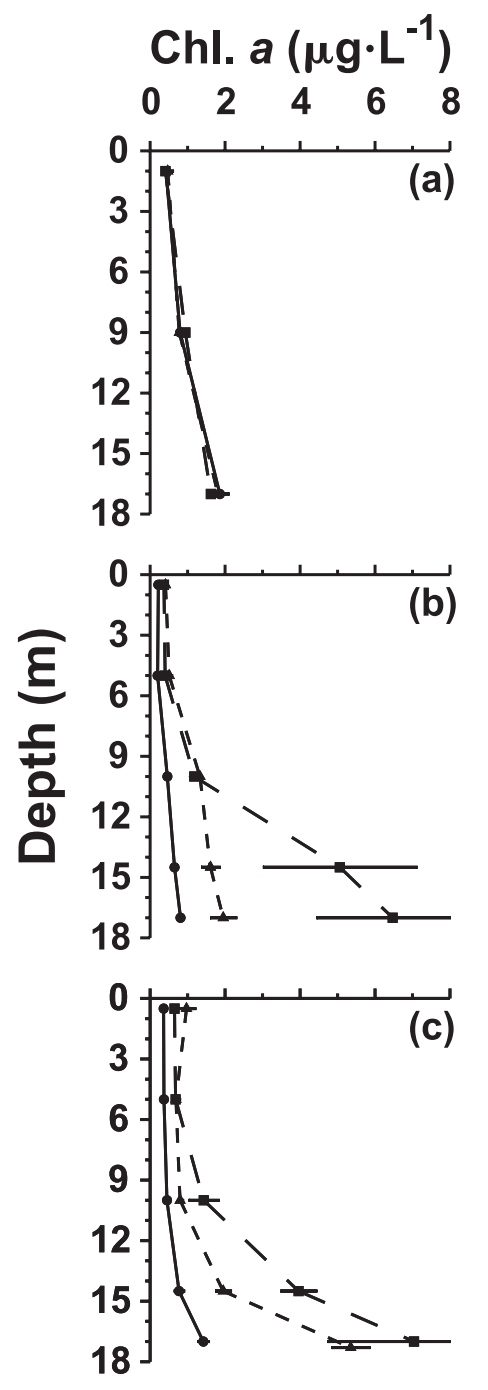

total integrated chlorophyll levels in the limnocorrals was highly significant (RM-ANOVA of log-transformed data, $p=0.004)$, there were no significant differences between EPI and META treatments (post-hoc contrast, $p=0.994$ ).

\section{Discussion}

The comparison of epilimnetic with metalimnetic fertilization in the limnocorrals indicates that the depth to which nutrients load into a lake will influence the vertical distribution of phytoplankton and periphyton production. Epilimnetic and metalimnetic nutrient additions also had different effects on phytoplankton biovolume, taxonomic composition, and chlorophyll levels of both phytoplankton and periphyton. Integrated whole water column measures of primary production, however, were similar in the two fertilization regimes.
Fig. 6. Mean water column chlorophyll $a$ concentrations in (a) epilimnetic and (b) 0 - to $17-\mathrm{m}$ integrated tube samples from the Pettit Lake limnocorrals during the 10-week experiment. Nutrient additions began on 3 July 1993. Shown are control (CNTL, - - epilimnetic (EPI, ○○), metalimnetic (META, $\boldsymbol{\nabla}-\mathbf{\nabla})$ fertilization treatments and epilimnetic chlorophyll levels in the lake during the course of the experiment $(\nabla-\cdots-\nabla)$. Bars on symbols indicate ranges for the duplicated limnocorral treatments $(n=2)$.

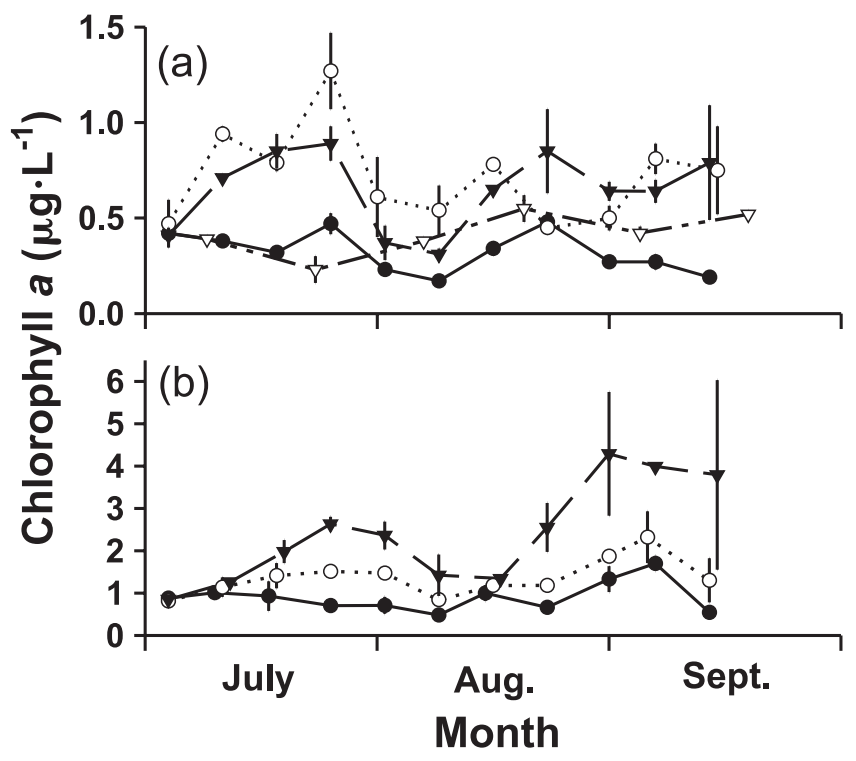

Fig. 7. Mean weekly Secchi depths in the experimental limnocorrals $(n=2)$. Control (CNTL, $\mathbf{\square} \cdots)$ and epilimnetic (EPI, $\triangle--\triangle$ ) and metalimnetic (META, - - ) fertilization treatments are shown. Bars on symbols indicate ranges for the duplicated limnocorral treatments $(n=2)$ when they extend beyond the symbols. Differences between treatments were highly significant (repeated measures ANOVA, $F_{[2,3]}=35.7, p=0.008$ ). Secchi depths in the lake $(\boldsymbol{\nabla}-\mathbf{-})$ during the study are also shown. Only a single measurement was made in the lake on each date.

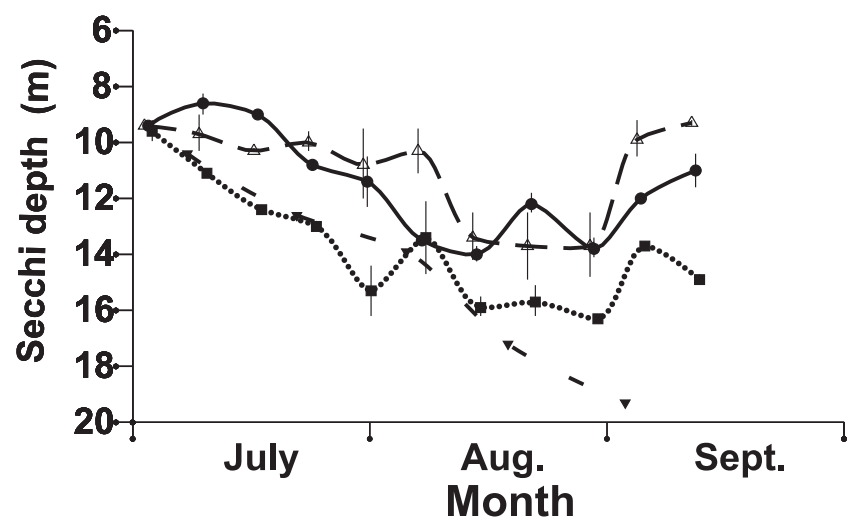

These experimental results demonstrated that both the epilimnetic and metalimnetic algae in the limnocorrals were nutrient limited and that neither ultraviolet light (Williamson 1996) nor $\mathrm{CO}_{2}$ (Fairchild and Sherman 1990) levels were dominant factors controlling epilimnetic production. Other authors have suggested that phytoplankton in the deep chlo- 
Fig. 8. Periphyton chlorophyll depth profiles on (a) 29 July, (b) 19 Aug, and (c) 14 September 1993 for limnocorrals receiving no additions (CNTL, - - ) or metalimnetic (META, $\mathbf{\Delta}-\mathbf{-}-\mathbf{\Delta}$ ) or epilimnetic (EPI, $\mathbf{-}_{-}-\mathbf{-}$ ) additions of $\mathrm{N}$ and P fertilizer. On each sampling date, integrated chlorophyll levels in all treatments were significantly different from each other except for the epilimnetic and metalimnetic treatments on 14 September (1-way ANOVA; post hoc Tukey's, $\alpha=0.05, n=2$ ). Bars on symbols indicate ranges for the duplicated limnocorral treatments $(n=2)$ when they extend beyond the symbols.

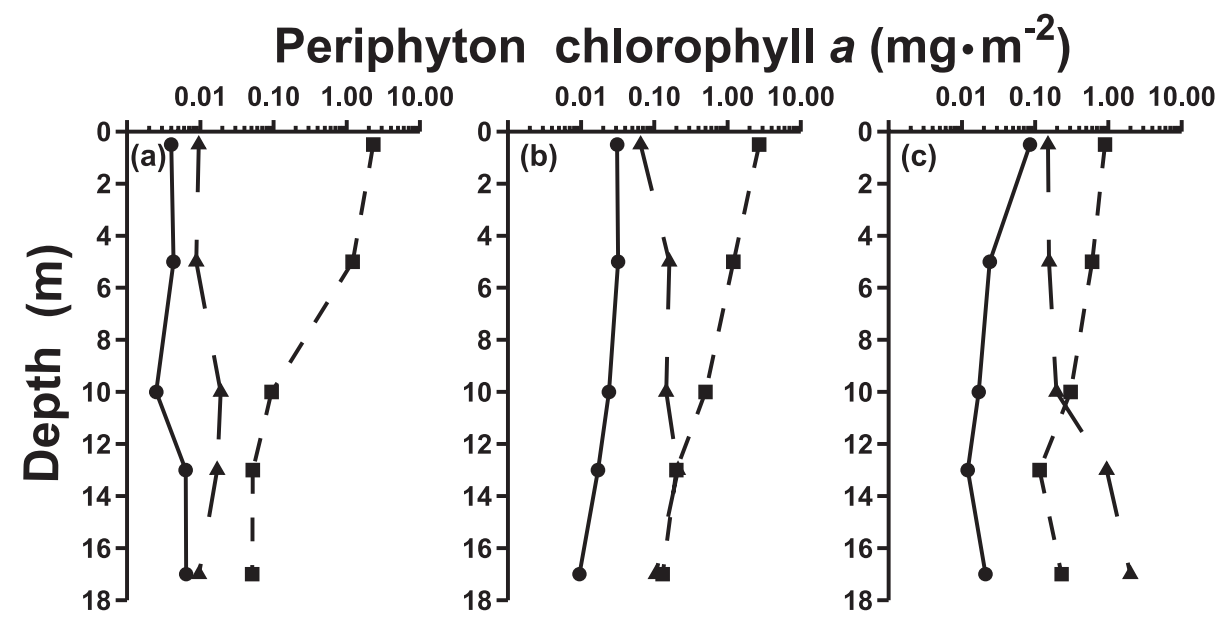

Fig. 9. Relative amounts of total chlorophyll $a$ in the periphyton and phytoplankton of the limnocorrals on (a) 29 July, (b) 19 August, and $(c) 14$ September. Total amounts were computed by integrating vertical profiles of phytoplankton or periphyton chlorophyll (Fig. 8) on each date. Control (CNTL), epilimnetic fertilization (EPI), and metalimnetic (META) treatments are shown. Solid bar represents periphyton chlorophyll; open bar represents phytoplankton chlorophyll.
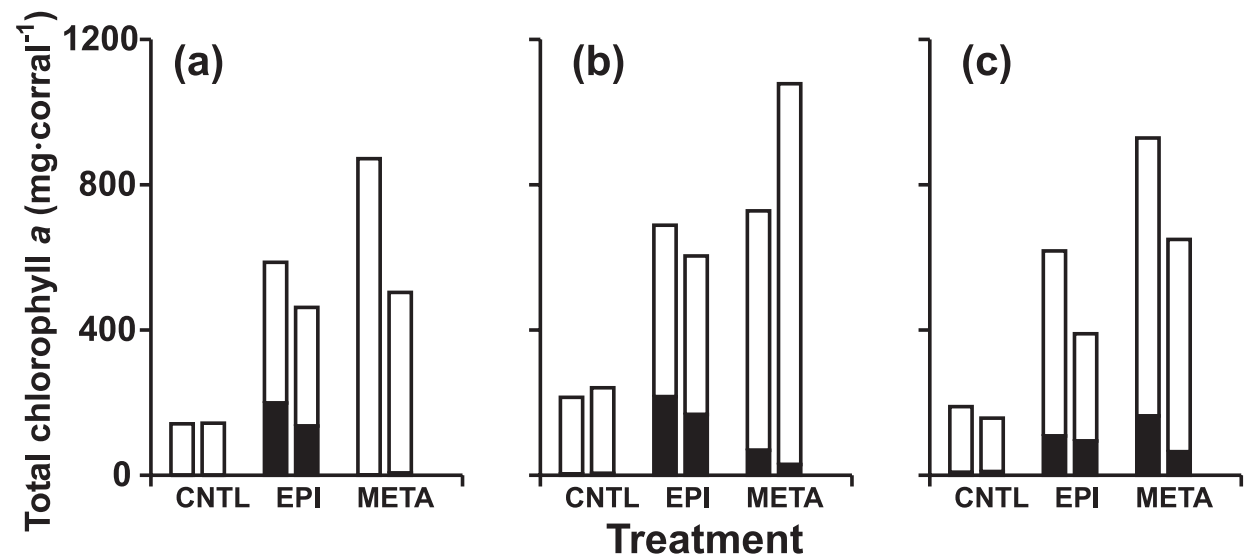

rophyll layer are limited by light, not by nutrients (e.g., Priscu and Goldman 1983; Huovinen et al. 1999). The strong response that we observed was likely because we fertilized the upper portion of the deep chlorophyll layer, where light levels ranged from $16 \%$ of surface intensities at $7 \mathrm{~m}$ to $1 \%$ at $17 \mathrm{~m}$. Pick et al. (1984) showed that nutrient deprivation was often very high in the upper portion of a deep chlorophyll layer but decreased markedly as the deep chlorophyll maxima was approached. Unfortunately, limnologists have often focused attention on the deep chlorophyll maxima rather than on the heterogeneity that can occur across the metalimnion. It is likely that the upper metalimnetic community is more important ecologically than the phytoplankton at the maxima because relatively little primary production occurs at, or below, the deep chlorophyll maxima where light levels are often below 1\% (e.g., Cullen 1982; Gross et al. 1997).

The limnocorral experiment indicates that metalimnetic nutrient fertilizations may provide advantages over epilimnetic additions in programs designed to promote fish production (i.e., sockeye salmon; Budy et al. 1997) especially when aesthetic impacts are important. The two strategies provided similar enhancement of primary production, but metalimnetic fertilization resulted in less periphyton and filamentous cyanobacteria growth, deeper Secchi depths, and greater phytoplankton biomass (as chlorophyll) than did the epilimnetic fertilization. Additionally, the dominant green algae stimulated in the metalimnetic fertilization treatments (Chlorella sp.) were of higher quality for cladocera than the sheathed Gloeocystis sp. and Oscillatoria sp. stimulated in the epilimnetic treatment (e.g., Knisely and Geller 1986; Sarnelle 1986; Sommer 1988), suggesting that deep fertilization may be as effective, or more effective, in stimulating zooplankton food resources compared with epilimnetic nutrient enrichment. The net benefit of increased algal production in the metalimnion for higher trophic levels is, however, unclear because zooplankton grazing rates may be slowed at the cold temperatures characteristic of the metalimnion and hypolimnion (Lampert 1987; C. Luecke, unpublished data). 
Additionally, the metalimnetic fertilization may have stimulated the abundant picocyanobacteria in the metalimnion that we did not measure. Unfortunately, the influence of both epilimnetic and metalimnetic fertilization on the macrozooplankton and fish in our experiment was unclear because high sampling variances precluded finding any possible stimulation (Gross et al. 1994). The high variances may have been caused by uneven predation pressure on the zooplankton resulting from fish mortalities in the limnocorrals and a tendency for the plankton to concentrate near the perimeters of limnocorrals (W.A. Wurtsbaugh, unpublished observation) where they may have been missed by our sampling procedure. In a similar limnocorral experiment done in a nearby oligotrophic lake, Budy et al. (1997) demonstrated that epilimnetic nutrient enrichment increased both zooplankton and fish production. Because of conflicting evidence over the importance of algae in deep layers for zooplankton (cf. Williamson et al. 1996; Dagg et al. 1997), additional research is needed on the relative importance of epilimnetic and metalimnetic phytoplankton as food resources for higher trophic levels.

Periphyton in the limnocorrals were nutrient limited and increased in response to nutrient additions even more than did the phytoplankton, consistent with other research indicating that near-surface periphyton populations can be strongly limited by nitrogen or phosphorus (e.g., Mazumder et al. 1989; Marks and Lowe 1993). Our results extend this observation by demonstrating that periphyton located in the metalimnetic strata can also be nutrient limited. Our results contrast with those of Turner et al. (1994), who reported that dissolved inorganic carbon limited extant periphyton communities where thick periphyton mats might have restricted the diffusion of dissolved inorganic carbon to the algae and where internal recycling of $\mathrm{N}$ and $\mathrm{P}$ might have reduced nutrient limitation. In contrast, our experiment accentuated the importance of nutrients during colonization and attachment, because the plastic limnocorral material was initially periphyton-free. Additionally, it is difficult to extend our results directly to the lake situation because algal growth on plastic limnocorral material may likely differ substantially from that on natural substrates (Burkholder 1996).

The high surface to volume ratio in the limnocorrals likely influenced the balance between periphyton and phytoplankton growth. Even though our limnocorrals were large, their surface area (of plastic) to volume ratio was 38 times greater than the sediment area to volume ratio in the top 17m-thick strata of the lake. Consequently, the relatively large proportion of chlorophyll that we observed in the periphyton communities in the fertilized limnocorrals would not occur in a whole lake with the morphometry of Pettit Lake. Nevertheless, in smaller lakes with a high proportion of sediments in the photic zone, epilimnetic fertilization may result in a large portion of nutrients entering the periphyton community instead of the phytoplankton (Axler and Reuter 1996), thus diverting nutrients from the pelagic food web.

Results of this limnocorral experiment should be extrapolated cautiously to a whole lake situation for several reasons. Firstly, the enclosed limnocorrals may have increased algal nutrient limitation by excluding sources of nutrients. It seems likely that some source of nutrients was excluded because during the latter part of the experiment epilimnetic chlorophyll levels in the control limnocorrals were about $50 \%$ of those in the lake and the nutrient additions reversed this trend. The limnocorrals may have blocked nutrients diffusing from the epilimnetic or metalimnetic sediments (Fee 1979; Levine and Schindler 1992; MacIntyre et al. 1999) and those from riverine inflows. In a lake, the temperature of the inflows will determine whether the nutrients are delivered to the epilimnion, metalimnion, or hypolimnion (Carmack et al. 1979; Vincent et al. 1991) and thus the impact on algal production in the different strata. Secondly, the enclosed limnocorrals would have stopped eddy diffusivity from potentially transporting nutrients upward from the hypolimnion, and they likely decreased diffusivity within the corrals (Bloesch et al. 1988). However, estimates of hypolimnetic-metalimnetic eddy diffusivity for Pettit Lake during summer stratification are about $0.052 \mathrm{~cm}^{2} \cdot \mathrm{s}^{-1}$, and this supplies only $1 \%$ of the dissolved inorganic nitrogen necessary to support primary production in the deep chlorophyll layer (W.A. Wurtsbaugh, unpublished data). Thirdly, the impacts of depth-specific nutrient loading will diverge through time. In our 10-week experiment, fertilization of both strata increased algal growth in the adjacent layers, indicating substantial nutrient transport between strata. Our weekly sampling with Secchi disks, water bottles, and zooplankton nets may have increased mixing between strata, thus accentuating this transport. Additionally, algal and fecal sedimentation (Reynolds 1984) will move epilimnetic nutrients downward, and diffusivity, albeit limited, will move nutrients upward. Also, if nutrients in plunging river inflows enter into a metalimnion, there will be a concomitant upward advection of water and nutrients into the epilimnion if the system has a surface outflow. Finally, nutrients that enter into different strata will be redistributed by seasonal mixing, eventually eliminating the effects of depth-specific loading.

Although limnocorral experiments may cause artifacts, our experimental results indicate that depth-specific nutrient loading can have important implications for the vertical structure of primary production and the distribution of algal biomass in lakes. Because limnocorrals do not entirely simulate natural conditions and modify mechanisms that redistribute nutrients in lakes, whole-lake experiments should be used to test the effects of fertilizing different lake strata and to understand how plunging inflows may influence production of phytoplankton and zooplankton in different strata.

\section{Acknowledgments}

We are indebted to T. Blenckner, G. Steinhart, S. Durham, D. Staab, D. Hunter, N. Bouwes, and J. Ruzycki for their help on the project. The logistical support from the staffs of the Shoshone-Bannock Indian Tribe, the Sawtooth National Recreation Area, and the Idaho Fish and Game facilitated the successful completion of the project. Funding was provided through the Shoshone-Bannock Indian Tribes (from the Bonneville Power Administration), a Vice-Presidential Fellowship from Utah State University to H.P.G., the Ecology Center at Utah State University, and the National Science Foundation (DEB 9726996).

\section{References}

American Public Health Association. 1992. Standard methods for 
the examination of water and wastewater. 18th ed. American Public Health Association, New York.

Axler, R.P., and Reuter, J.E. 1996. Nitrate uptake by phytoplankton and periphyton: whole-lake enrichments and mesocosm- ${ }^{15} \mathrm{~N}$ experiments in an oligotrophic lake. Limnol. Oceanogr. 41: 659-671.

Bloesch, J., Bossard, P., Bührer, H., Bürgi, H.R., and Uehlinger, D. 1988. Can results from limnocorral experiments be transferred to in situ conditions? Biomanipulation in limnocorrals VI. Hydrobiologia, 159: 297-308.

Budy, P., Luecke, C., Wurtsbaugh, W.A., Gross, H.P., and Gubala, C.P. 1995. Limnology of the Sawtooth Valley lakes with respect to potential growth of juvenile Snake River sockeye salmon. Northwest Sci. 69: 133-150.

Budy, P., Luecke, C., and Wurtsbaugh, W.A. 1997. Adding nutrients to enhance the growth of endangered sockeye salmon: trophic transfer in an oligotrophic lake. Trans. Am. Fish. Soc. 127: 19-34.

Burkholder, J.M. 1996. Interactions of benthic algae with their substrata. In Algal ecology: freshwater benthic ecosystem. Edited by R.J. Stevenson, M.L. Bothwell, and R.L. Lowe. Academic Press, San Diego, Calif. pp. 253-297.

Carmack, E.C., Gray, C.B.J., Pharo, C.H., and Daley, R.J. 1979. Importance of lake-river interaction on seasonal patterns in the general circulation of Kamloops Lake, British Columbia. Limnol. Oceanogr. 24: 634-644.

Crumpton, W.G. 1987. A simple and reliable method for making permanent mounts of phytoplankton for light and fluorescence microscopy. Limnol. Oceanogr. 32: 1154-1159.

Cullen, J.J. 1982. The deep chlorophyll maximum: comparing vertical profiles of chlorophyll $a$. Can. J. Fish. Aquat. Sci. 39: 791-803.

Dagg, M.J., Frost, B.W., and Newton, J.A. 1997. Vertical migration and feeding behavior of Calanus pacificus females during a phytoplankton bloom in Dabob Bay, U.S. Limnol. Oceanogr. 42: 974-980.

Downing, J.A., Osenberg, C.W., and Sarnelle, O. 1999. Meta-analysis of marine nutrient-enrichment experiments: variation in the magnitude of nutrient limitation. Ecology, 80: 1157-1167.

Fairchild, G.W., and Sherman, J.W. 1990. Effects of liming on nutrient limitation of epilithic algae in an acid lake. Water Air Soil Pollut. 52: 133-147.

Fee, E.J. 1979. A relation between lake morphometry and primary productivity and its use in interpreting whole-lake eutrophication experiments. Limnol. Oceanogr. 24: 401-416.

Gross, H.P., Wurtsbaugh, W.A., Luecke, C., and Budy, P. 1994. Comparison of epilimnetic and metalimnetic fertilizations on the phytoplankton and zooplankton in Pettit Lake, Idaho. In Snake River sockeye salmon habitat and limnological research-annual report 1993. Edited by D. Teuscher et al. U.S. Department of Energy, Bonneville Power Administration DOE/BP-22548-2, Portland, Oregon (http://www.bpa.gov/cgi-scripts/support/info_ request.asp). pp. 78-99.

Gross, H.P., Wurtsbaugh, W.A., Luecke, C., and Budy, P. 1997. Fertilization of an oligotrophic lake with a deep chlorophyll maximum: predicting the effect on primary productivity. Can. J. Fish. Aquat. Sci. 54: 1177-1189.

Gross, H.P., Wurtsbaugh, W.A., and Luecke, C. 1998. The role of anadromous sockeye salmon (Oncorhynchus nerka) in the nutrient loading and productivity of the Sawtooth Valley Lakes, Idaho. Trans. Am. Fish. Soc. 127: 1-18.

Hillebrand, H., Dürselen, C.-D., Kirschtel, D., Pollingher, U., and Zohary, T. 1999. Biovolume calculation for pelagic and benthic microalgae. J. Phycol. 35: 403-424.

Holm-Hansen, O., and Riemann, B. 1978. Chlorophyll-a determination: improvements in methodology. Oikos, 30: 438-447.

Huovinen, P.S., Brett, M.T., and Goldman, C.R. 1999. Temporal and vertical dynamics of phytoplankton net growth in Castle Lake, California. J. Plankton Res. 21: 373-387.

Knisely, K., and Geller, W. 1986. Selective feeding of four zooplankton species on natural lake phytoplankton. Oecologia, 69: 86-94.

Lampert, W. 1987. Feeding and nutrition in Daphnia. In Memorie dell'Istituto Italiano di Idrobiologia 45: Daphnia. Edited by R.H. Peters and R. De Bernardi. Istituto Italiano di Idrobiologia, Pallanza, Italy. pp. 143-192.

LeBrasseur, R.J., McAllister, C.D., Barraclough, W.E., Kennedy, O.D., Manzer, J., Robinson, D., and Stephens, K. 1978. Enhancement of sockeye salmon (Oncorhynchus nerka) by lake fertilization in Great Central Lake: summary report. J. Fish. Res. Board Can. 35: 1580-1596.

Levine, S.N., and Schindler, D.W. 1992. Modification of the N:P ratio in lakes by in situ processes. Limnol. Oceanogr. 37: 917-935.

MacIntyre, S., Flynn, K.M., Jellison, R., and Romero, J.R. 1999. Boundary mixing and nutrient fluxes in Mono Lake, California. Limnol. Oceanogr. 44: 512-529.

Marks, J.C., and Lowe, R.L. 1993. Interactive effects of nutrient availability and light levels on the periphyton composition of a large oligotrophic lake. Can. J. Fish. Aquat. Sci. 50: 1270-1278.

Mazumder, A., Taylor, W.D., McQueen, D.J., and Lean, D.R.S. 1989. Effects of nutrients and grazers on periphyton phosphorus in lake enclosures. Freshwater Biol. 22: 405-415.

Peters, R.H. 1984. Methods for the study of feeding, grazing and assimilation by zooplankton. In A manual on methods for the assessment of secondary productivity in fresh waters. Edited by J.A. Downing and F.H. Rigler. Blackwell Scientific, Oxford. pp. 336-412.

Pick, F.R., Lean, D.R.S., and Nalewajko, C. 1984. Nutrient status of metalimnetic phytoplankton peaks. Limnol. Oceanogr. 29: 960-971.

Prescott, G.W. 1978. How to know the freshwater algae. W.M.C. Brown, Dubuque, Iowa.

Priscu, J.C. 1995. Phytoplankton nutrient deficiency in lakes of the McMurdo dry valleys, Antarctica. Freshwater Biol. 34: 215-227.

Priscu, J.C., and Goldman, C.R. 1983. Seasonal dynamics of the deep-chlorophyll maximum in Castle Lake, California. Can. J. Fish. Aquat. Sci. 40: 208-214.

Reuter, J.E., Loeb, S.L., Axler, R.P., Carlton, R.G., and Goldman, C.R. 1985. Transformations of nitrogen following an epilimnetic $\mathrm{N}$-fertilization in Castle Lake, CA: 1. Epilithic periphyton responses. Arch. Hydrobiol. 102: 425-433.

Reynolds, C.S. 1984. The ecology of freshwater phytoplankton. Cambridge University Press, Cambridge.

Sarnelle, O. 1986. Field assessment of the quality of phytoplanktonic food available to Daphnia and Bosmina. Hydrobiologia, 131: 47-56.

SAS Institute, Inc. 1988. SAS/STAT user's guide. Release 6.03 ed. SAS Institute, Inc., Cary, N.C.

Schindler, D.W., Ruszcynski, T., and Fee, E.J. 1980. Hypolimnion injection of nutrient effluents as a method for reducing eutrophication. Can. J. Fish. Aquat. Sci. 37: 320-327.

Sommer, U. 1988. Phytoplankton succession in microcosm experiments under simultaneous grazing pressure and resource limitation. Limnol. Oceanogr. 33: 1037-1054.

St. Amand, A., and Carpenter, S.R. 1993. Metalimnetic phytoplankton dynamics. In The trophic cascade in lakes. Edited by S.R. Carpenter and J.K. Kitchell. Cambridge University Press, Cambridge. pp. 210-224.

Turner, M.A., Howell, E.T., Robinson, G.G.C., Campbell, P., Hecky, R.E., and Schindler, E.U. 1994. Roles of nutrients in controlling growth of epilithon in oligotrophic lakes of low alkalinity. Can. J. Fish. Aquat. Sci. 51: 2784-2793. 
Vincent, W.F., Gibbs, M.M., and Spigel, R.H. 1991. Eutrophication processes regulated by a plunging river inflow. Hydrobiologia, 226: $51-63$.

Williamson, C.E. 1996. Effects of UV radiation on freshwater ecosystems. Int. J. Environ. Stud. 51: 245-256.

Williamson, C.E., Sanders, R.W., Moeller, R.E., and Stutzman, P.L. 1996. Utilization of subsurface food resources for zooplankton production: implications for diel migration theory. Limnol. Oceanogr. 41: 224-233.

Wurtsbaugh, W.A., Gross, H.P., Luecke, C., and Budy, P. 1997. Nutrient limitation of oligotrophic sockeye salmon lakes of Idaho (USA). Verh. Int. Ver. Limnol. 26: 413-419. 